\title{
Influence of spacing on the feeding activities of major pests of sunflower and their associated damage
}

\author{
Akinkunmi, O.Y*, Akintoye, H.A, Umeh, V.C and AdeOluwa, O.O. \\ National Horticultural Research Institute P.M.B. 5432, Ibadan, Nigeria.
}

\begin{abstract}
The experiment was conducted in the Floriculture experimental field of National Horticultural Research Institute (NIHORT) Ibadan, Oyo State, Nigeria $\left(3^{\circ} 52^{\prime} \mathrm{E}\right.$ and $\left.7^{0} 25^{\prime} \mathrm{N}\right)$ between August and November 2009 and repeated between July and October 2010. Sunflower seeds were sown directly on prepared field using the following spacing: $65 \mathrm{~cm} \times 75 \mathrm{~cm}, 75 \mathrm{~cm} \times 75 \mathrm{~cm}, 85 \mathrm{~cm} \times 75$ $\mathrm{cm}$ and $100 \mathrm{~cm} \times 75 \mathrm{~cm}$ on $3 \mathrm{~m}$ by $3 \mathrm{~m}$ plot size with $1 \mathrm{~m}$ distance between and within plot and laid out in a randomized complete block design (RCBD) with three replicates. The insects observed were: the Sunflower beetle (Zygogramma exclamationis Fabricius (Coleoptera: Chrysomelidae), Spittlebug (Poophilus adustus Walker (Hemiptera: Cercopoidae), Variegated grasshopper (Zonocerus variegatus Linnaeus Orthoptera: Pyrgomorphidae), Sunflower stem weevil (Cylindrocopturus adspersus Leconte (Coleoptera: Curculionidae), Pachnoda cordata Drury (Coleoptera: Cetoniidae) and Atelocera raptoria Germar (Hemiptera: Pentatomidae). Spacing $65 \mathrm{~cm} \times 75 \mathrm{~cm}$ significantly gave a high insect population than other treatments while lowest insect population and highest seed yield were observed in spacing $100 \mathrm{~cm} \times 75 \mathrm{~cm}$. The highest damaged leaves $(48.60,51.25)$, stems $(22.25,25.10)$, and flower heads $(23.50$ and 27.20 ) in 2009 and 2010 respectively were observed in plants with $65 \mathrm{~cm} \times 75 \mathrm{~cm}$ spacing.
\end{abstract}

Keywords: Sunflower, Insect Pests, Spacing, Damage.

\section{INTRODUCTION}

Sunflower (Helianthus annuus L.) originated from North America (Janet et al, 2010). It is an ornamental crop that is cultivated widely throughout the world, and it belongs to the family Asteraceae (Groove and Summer, 2005). As an annual, short season growing plant which is easily identifiable by a large bright yellow flower head. Its popularity as cut flower has increased and thereby enhancing the aim of diversifying its advantage. The current world area under sunflower cultivation is 22.3 million hectare while seed production and average yield stands at 27.7I million tons and 1.2 ton/ha respectively (FAO, 2004). Sunflower has many uses and traditions associated with it. It has been used for food, in therapeutic, cosmetics and in many ancient traditions. The plant is one of the world's most important oil producing crops. The oil (which is derived from the seeds) accounts for about $80 \%$ of the value of the crop. Sunflower is a very suitable component crop for crop rotation, since it has shorter season than most crops, so it can be planted later or harvested earlier. The popularity is also due to the ease of cultivation. Sunflower can grow easily in many types of soil as long as they have direct sunlight and a constant source of water. Plant density is invariably linked with yield. The more the plant stands, the higher the expected production (Bertoria et al, 1998). Also Robinson et al, 1980, reported an increase in sunflower population which resulted in increased yield. The major hazards to sunflower production are insect pests. Over the years insect pests have become a major yield-reducing factor in its production (Carl, 1990). Some insects are occasional pests while a few are observed to cause damages as early as the seedling stage. As the plant grows, many insects feed on the foliage of the plant resulting in an increase in insect population, particularly when the flower bud has begun to develop. Some of these insects serve as vector for virus and other diseases. Over 150 phytophagous insect species have been reported from cultivated and wild sunflower, but only a few of these insects have adapted to environment and have become economic pests (Rogers et al, 1983, Rogers 1992). These insect pests attack the leaves, stems, flower heads as well as the seeds and cause economic loss in sunflower production and which is related in reduced seed yield and quality, as well as oil extracted from the seeds. Sunflower acts as host of several insects which ravage the crop both in the field as well as the storage and inflict severe losses (Irum, 2009). Some of the pests ravaging the crop include: the green sting bug (Nezera viridula Linnaeus), cut worm (Agrotis spp.), American bollworm 
Helicoverpa (Heliothis) armigera,cotton aphid (aphis gossypii Glov) and potato aphids (Lacrosiphum euphorbiae Tho), others include (Zygogramma exclamatiosis) sunflower beetle, (Melanagromyza Spp. stem girdler, Empoasca Spp., (Suleima heliathana) sunflower bud moth,(Helicoverpa spp.) bullworm, (Homoeosoma electrum) sunflower moth, Sunflower stem weevil (Cylindrocopturus adspersus Leconte, white fly (Bemisia tabaci) and grasshopper (Aslam et al.,2000, Ashfaq, M. and Aslam, M. 2001, Sattar, et al.,1984). On the other hand, plant spacing and number of plant per unit area of land are major factors that influence yield (Muhammad and Shamshad, 1998). Crop planting density has been reported to affect insect population dynamics (Soroja and Raja 1982). According to Asiwe et al., (2004) and Victor and Reuben (2000), the severity of insect infestation increased with increase in plant spacing. Similarly, Ukwungwu, (1982) reported increased gall midge damage at increased plant population on rice.

The aim of this study was to monitor the influence of spacing on the population dynamics of major insect pests of Sunflower and to evaluate damage on the plant.

\section{METHODOLOGY}

The trial was conducted in the Floriculture experimental field of National Horticultural Research Institute Ibadan, Oyo State, Nigeria $\left(3^{0} 52^{\prime} \mathrm{E}\right.$ and $7^{0}$ $25^{\prime} \mathrm{N}$ ), between August and November 2009 and July to October 2010. The plot size used was $3 \mathrm{~m} \times 3 \mathrm{~m}$ with $1 \mathrm{~m}$ furrow between each bed. Sunflower seeds were sown directly on prepared plots using the following spacing: $65 \mathrm{~cm} \times 75 \mathrm{~cm}, 75 \mathrm{~cm} \times 75 \mathrm{~cm}, 85$ $\mathrm{cm} \times 75 \mathrm{~cm}$ and $100 \mathrm{~cm} \times 75 \mathrm{~cm}$. The experiment was arranged in a Randomized Complete Block Design (RCBD) and replicated three times. Major insect pests were collected weekly, on six randomly selected tagged plants per plot from two weeks after planting (2 WAP) till maturity. The insects were handpicked in the early hours of the day from the leaves, stems and flower heads and were placed in kilner jars and later taken to the laboratory for identification using identification keys obtain from the insect Museum in the entomology unit of National Horticultural Research Institute, Ibadan.
Number of leaves per plant (from the selected plants) were recorded and graded as either damaged (when leaves show sign of insect feeding) or as undamaged. Percentages of damaged leaves, stems and flower heads were determined per plot by inspecting for damage associated with feeding activities. Seed weight per plot was also determined. Data collected were subjected to statistical analysis at 0.05 probability level.

\section{RESULTS}

The major insect pests observed were: the Sunflower beetle (Zygogramma exclamationis Fabricius (Coleoptera: Chrysomelidae), Spittlebug (Poophilus adustus Walker (Hemiptera: Cercopoidae), Variegated grasshopper (Zonocerus variegatus Linnaeus Orthoptera: Pyrgomorphidae), Sunflower stem weevil (Cylindrocopturus adspersus Leconte (Coleoptera: Curculionidae), Pachnoda cordata Drury (Coleoptera: Cetoniidae) and Atelocera raptoria Germar (Hemiptera: Pentatomidae). The occurrence of the larvae of Sunflower moth (Homoeosoma ellectellum Hulst (Lepidoptera: Pyralidae) was low. Pachnoda cordata, poophilus spp, Atelocera raptoria and Sunflower moth were found on the plant only during the vegetative stage. Sunflower stem weevil and were found in the flowering stage while Spittlebug, Sunflower beetle and Grasshopper were found both at the vegetative and flowering stages. Insect population was affected by the spacing used as shown in Table 1. Plant spacing of $65 \mathrm{~cm} \times 75 \mathrm{~cm}$ (i.e high density) gave higher insect population in both years than other spacing. Lowest insect population was observed in spacing $100 \mathrm{~cm} \times 75 \mathrm{~cm}$. The occurrence of sunflower beetle was higher than any other insect encountered within the period of the trial (Table 1). The highest damaged leaves (48.60, $51.25)$,stems $(22.25,25.10)$, and flower heads (23.50 and 27.20) in 2009 and 2010 respectively were encountered in plants with $65 \mathrm{~cm} \times 75 \mathrm{~cm}$ spacing while at low density of spacing $100 \mathrm{~cm} \times 75 \mathrm{~cm}$ damage on the leaves, stem and flower head was significantly reduced (Table 2). At maturity, the flower head containing the seeds significantly had a higher weight $(5.10,5.00)$, subsequently Seed yield weight was significantly higher $(3.94,3.65)$ in $100 \mathrm{~cm} \times 75 \mathrm{~cm}$ plant spacing both in 2009 and 2010 respectively compared to other spacing used (Table 3 ).

Table 1: The population count of key insect pests of Sunflower under different plant spacing. 


\begin{tabular}{|l|l|l|l|l|l|l|l|l|}
\hline Plant spacing & \multicolumn{2}{l|}{ Sunflower betle } & \multicolumn{2}{l|}{ Poophilus } & \multicolumn{2}{l|}{ Stem borer } & \multicolumn{2}{l|}{. Cordata } \\
\hline & 2009 & 2010 & 2009 & 2010 & 2009 & 2010 & 2009 & 2010 \\
\hline $65 \times 75 \mathrm{~cm}$ & $20.35 \mathrm{a}$ & $25.23 \mathrm{a}$ & $14.10 \mathrm{a}$ & $13.45 \mathrm{a}$ & $15.50 \mathrm{a}$ & $18.05 \mathrm{a}$ & $14.20 \mathrm{a}$ & $17.10 \mathrm{a}$ \\
\hline $75 \times 75 \mathrm{~cm}$ & $16.20 \mathrm{~b}$ & $19.10 \mathrm{~b}$ & $10.00 \mathrm{~b}$ & $11.57 \mathrm{~b}$ & $9.37 \mathrm{~b}$ & $10.30 \mathrm{~b}$ & $9.50 \mathrm{~b}$ & $12.40 \mathrm{~b}$ \\
\hline $85 \times 75 \mathrm{~cm}$ & $8.00 \mathrm{c}$ & $11.20 \mathrm{c}$ & $7.20 \mathrm{c}$ & $9.15 \mathrm{c}$ & $6.45 \mathrm{c}$ & $9.00 \mathrm{c}$ & $7.80 \mathrm{c}$ & $9.00 \mathrm{c}$ \\
\hline $100 \times 75 \mathrm{~cm}$ & $7.15 \mathrm{~d}$ & $10.90 \mathrm{~d}$ & $6.80 \mathrm{c}$ & $8.00 \mathrm{~d}$ & $5.35 \mathrm{~d}$ & $8.50 \mathrm{c}$ & $4.00 \mathrm{~d}$ & $7.45 \mathrm{~d}$ \\
\hline
\end{tabular}

Means with the same letters are not significantly different at $(P>0.05)$

Table 2: Insect damage on the leaves, stems and flower heads of Sunflower.

\begin{tabular}{|l|l|l|l|l|l|l|}
\hline Plant spacing & \multicolumn{2}{l|}{ Leaves damage (\%) } & \multicolumn{2}{l|}{ Stem damage (\%) } & \multicolumn{2}{l|}{ Flower head damage (\%) } \\
\hline & 2009 & 2010 & 2009 & 2010 & 2009 & 2010 \\
\hline $65 \times 75 \mathrm{~cm}$ & $48.60 \mathrm{a}$ & $51.25 \mathrm{a}$ & $22.25 \mathrm{a}$ & $25.10 \mathrm{a}$ & $23.50 \mathrm{a}$ & $27.20 \mathrm{a}$ \\
\hline $75 \times 75 \mathrm{~cm}$ & $35.13 \mathrm{~b}$ & $42.10 \mathrm{~b}$ & $15.40 \mathrm{~b}$ & $18.85 \mathrm{~b}$ & $19.20 \mathrm{~b}$ & $21.50 \mathrm{~b}$ \\
\hline $85 \times 75 \mathrm{~cm}$ & $24.10 \mathrm{c}$ & $32.30 \mathrm{c}$ & $9.25 \mathrm{c}$ & $10.00 \mathrm{c}$ & $15.00 \mathrm{c}$ & $18.00 \mathrm{c}$ \\
\hline $100 \times 75 \mathrm{~cm}$ & $20.55 \mathrm{~d}$ & $20.55 \mathrm{~d}$ & $4.45 \mathrm{~d}$ & $6.35 \mathrm{~d}$ & $14.00 \mathrm{c}$ & $16.35 \mathrm{~d}$ \\
\hline
\end{tabular}

Means with the same letters are not significantly different at $(\mathrm{P}>0.05)$

Table 3: Effect of insect damage on weight of flower heads and Seed yield of Sunflower.

\begin{tabular}{|l|l|l|l|l|}
\hline Plant spacing & Flower head $(\mathrm{t} / \mathrm{ha})$ & \multicolumn{2}{l|}{ Seed yield(t/ha) } \\
\hline & 2009 & 2010 & 2009 & 2010 \\
\hline $65 \times 75 \mathrm{~cm}$ & $2.60 \mathrm{~d}$ & $2.42 \mathrm{~d}$ & $1.95 \mathrm{~d}$ & $1.75 \mathrm{~d}$ \\
\hline $75 \times 75 \mathrm{~cm}$ & $3.00 \mathrm{c}$ & $2.85 \mathrm{c}$ & $2.85 \mathrm{c}$ & $2.30 \mathrm{c}$ \\
\hline $85 \times 75 \mathrm{~cm}$ & $4.91 \mathrm{~b}$ & $4.05 \mathrm{~b}$ & $3.18 \mathrm{~b}$ & $3.08 \mathrm{~b}$ \\
\hline $100 \times 75 \mathrm{~cm}$ & $5.10 \mathrm{a}$ & $5.00 \mathrm{a}$ & $3.94 \mathrm{a}$ & $3.65 \mathrm{a}$ \\
\hline
\end{tabular}

Means with the same letters are not significantly different at $(P>0.05)$

\section{DISCUSSION:}

The insects observed on the field were Sunflower beetle (Zygogramma exclamationis Fabricius (Coleoptera: Chrysomelidae), Spittlebug (Poophilus adustus Walker (Hemiptera: Cercopoidae), Variegated grasshopper (Zonocerus variegatus Linnaeu Orthoptera: Pyrgomorphidae), Sunflower stem weevil (Cylindrocopturus adspersus Leconte), and this is in line with the findings of (Aslam et al., 2000, Ashfaq, M. and Aslam, M. 2001 and Sattar, et al., 1984. This implies that similar trend of insects can be observed on sunflower irrespective of the locations. The occurrence of sunflower beetle was higher than any other insect encountered within the period of the trial (Table 1). This must be as a result of the occurrence of this insect throughout the growing stages of the plant. Also, spacing significantly affected the population of the insect pests in the experiment. At the lowest spacing $65 \mathrm{~cm}$ $x 75 \mathrm{~cm}$, sunflower population density was high, this resulted into a higher insect population since there was increase in the amount of food available for the insects to feed upon. However, at higher spacing especially at $100 \mathrm{~cm} \times 75 \mathrm{~cm}$, there was a reduction in the sunflower population and subsequently a reduction in the availability of food which resulted into a lower insect population recorded in the plot. Similar trend was reported by Soroja and Raju in 1982. Furthermore, previous study by Asiwe, et al., (2004) revealed that, the severity of damage on plants by insect infestation increased with reduction in plant spacing. In 2009, spacing $65 \mathrm{~cm} \times 75 \mathrm{~cm}$ gave a significantly higher percentage of leaves, stem and flower head damage compared to other spacing used in the trial. Similar trend was also observed in 2010. This is associated with higher insect population recorded on the plot. Damage on the leaves, stem or flower head contributed to the reduction in total yield. Seed yield and seed weight increased with fewer insects occurrence as plant spacing increased, this is in line with the findings of Victor and Reuben in 2000. More seeds yield and higher seed weight (1.95t/ha, $1.75 \mathrm{t} / \mathrm{ha}$ ) was derived from plots with spacing $100 \mathrm{~cm}$ $x 75 \mathrm{~cm}$ both in 2009 and 2010 respectively, this is as a result of fewer insect recorded on the plot. The 
seed yield derived in 2009 was higher than in 2010, this was as a result of higher insect population recorded in year 2010 which resulted into a higher damage to the leaves, stem and flower heads of sunflower.

\section{CONCLUSION:}

Sunflower production like other economic crops is faced with diverse set-backs of which insect pests is paramount. Introducing planting space will reduce the population of insects as well as reduce damage which will increase the yield of the crop. At lower spacing $65 \mathrm{~cm} \times 75 \mathrm{~cm}$, insect population was higher, due to higher density of the plant and this resulted into higher damage done to the plant and a reduction in the seed yield but the reverse occurred at a higher plant spacing of $100 \mathrm{~cm} \times 75 \mathrm{~cm}$ in both years of the trial.

\section{ACKNOWLEDGEMENT}

The immerse contributions of the following people are really appreciated in making this work a success: Dr and Mrs Shokalu, Mrs Oyewo, Mr Olaleye and Mrs Fajinmi

\section{REFERENCES:}

Aduayi, E.A., Chude, V.O., Adebusuyi, B.A. and Olayiwola, S.O. (2002). Fertilizer use and Management practices for crops in Nig. Fed. Ministry of Agric. And Rural Debt. Abuja, Nig. P: 63-65.

Asiwe, J.A.N., Nook, S., Jackal L.E.N., and Ewete, F.K. (2004). Increased severity in Aphid Infestation with increased in Plant Spacing. Journal of Crop Protection Vol. 24: 465- 467.

Ashfaq, M and Aslam, M. (2001). Resistance of different Sunflower (Helianthus annuls L.) genotype against The attack of Aphis gossypii Glover, Nezera viridula (L.) and Trips tabaci Lind, in field. Journal of Biological Sciences 1:941-945.

Aslam, M., Suleman, N., Riaz, A., Rehman, A and Zia, Q. (2000). Insect Pests found on Helianthus annus L.(Compositae) in the Potophar region of Pakistan. Pakistan Journal of Biological Sciences 3:963-964.

Bertoria, L.R, Burak A and A Nivio. (1998). Effect of plant densities on yield and quality of forage maize. Maize
Growers Co-operative Newsletter, Santa Caterina, Brazil.

Carl, D. Patrick. (1990). Managing Insect Pests of Texas Sunflower. Texas Agricultural Extension Services.

FAO (2004). Food and Agricultural Organization of United Nations.2004. FAOSTAT Database.

Groove, J.H and Summer, M.E. (2005). Yield and leaf composition of sunflower in relation to N.P.K. and lime treatment in nutrient cycling. Agro ecosystems. $3:(4)$ : 367-378.

Irum, M. (2009). Sunflower disease and Insect Pests in Parkistan : A Review. African Crop Science Journal 17 (2): 109-118.

Mohammad, A and Shamshad A. K. (1998). Plant spacing and number of plant per hill in Sunflower Production. Pakistan J. Agric. Res. 9 (1): 76-78.

Robinson, R.G., J.H Ford, W.E. Leus Chem D.D Warnes and J.V.Wier Sma., 1980. Response of

Sunflower to plant population. Agron. J. 72: 869-871.

Rogers, C.E, 1992. Insect Pests and Strategies for their Management in cultivated Sunflower. Field Crops Res. 30:301-332.

Rogers, C. E., Unger, P.W., Archer T.L. and Bynum, E.D. Jr., 1983. Management of a stem weevil: Cylindrocopturus adspersus (Le-conte) (Coleoptera : Curculionidae) on Sunflower in the Northern Great Plains. J. Econ. Entomology. 76(4): 952-956.

Sattar, A.,Ullah, K and Yousaf, M. 1984. Insect Pests of Sunflower in NWFP, Pakistan. Journal of Agriculture Resources. 5: 239-240.

Soroja, R.N AND Raja, N. 1982. Effect of nitrogen fertilizer levels and spacing on rice gall midge and leaf folder damage. IRRN. 7 (4) 10.Ukwungwu, M.N. 1987. Effect of spacing and Nitrogen fertilization on infestation by the rice gall midge,

Orseolia oryzivora. Harris and Gagne ( Diptera: Cecidoniyiidae) in Nigeria Tropical Pest Management. 33(2) 164-165.

Victor, T.J and Reuben, R. 2000. Effect of spacing on the population of mosquito immature in rice fields in Madurai, South Africa. Indian Journal Molariol. 37 (12): $18-26$. 